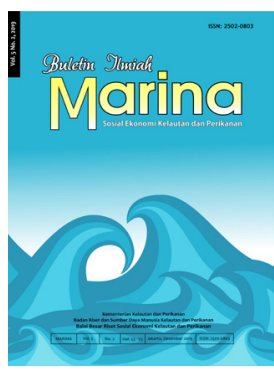

BULETIN ILMIAH MARINA

SOSIAL EKONOMI KELAUTAN DAN PERIKANAN

http://ejournal-balitbang.kkp.go.id/index.php/mra

p-ISSN: 2502-0803

e-ISSN: 2541-2930

Nomor Akreditasi: 10/E/KPT/2019

\title{
INDUSTRI PENGOLAHAN PERIKANAN DI KABUPATEN KONAWE SELATAN, SULAWESI TENGGARA
}

\section{Fish Processing Industry in South Konawe Regency, South East Sulawesi}

\author{
*Ernawati, Muhammad Rafiy, dan Surianti \\ Fakultas Ekonomi dan Bisnis, Universitas Halu Oleo Kambu, \\ Jl. Kambu, Kec. Kambu, Kota Kendari, Sulawesi Tenggara 93561, Indonesia \\ Diterima tanggal: 7 Mei 2019 Diterima setelah perbaikan: 23 Mei 2020 \\ Disetujui terbit: 26 Juni 2020
}

\begin{abstract}
ABSTRAK
Penelitian ini bertujuan untuk mengkaji ketersediaan bahan baku dan skala pemasaran industri pengolahan hasil perikanan di Kabupaten Konawe Selatan. Penelitian dilaksanakan pada tahun 2017 dan 2018 dengan menggunakan data primer dan sekunder. Data primer diperoleh melalui kuesioner yang didistribusikan kepada 21 responden pelaku usaha. Data sekunder diperoleh melalui publikasi Badan Pusat Statistik (BPS), Dinas Kelautan dan Perikanan, serta Dinas Perindustrian dan Perdagangan Kabupaten Konawe Selatan. Data diolah melalui analisis deskriptif dan SWOT. Hasil penelitian menunjukkan bahwa kekuatan industri pengolahan hasil perikanan di Kabupaten Konawe Selatan karena bahan baku bersumber dari potensi lokal, namun kelemahannya adalah bahan baku tersebut masih fluktuatif. Kendala bahan baku dialami khususnya oleh industri fermentasi, pengasapan, dan pengeringan ikan. Selain faktor musiman, ketersediaan bahan baku juga terkendala karena bahan baku sebagian besar berasal dari nelayan tradisional dengan struktur armada perikanan yang didominasi oleh nelayan skala kecil. Dengan demikian, pengembangan industri hasil perikanan mensyaratkan perbaikan di sektor hulu melalui sinergitas kebijakan penanganan keterbatasan bahan baku dari berbagai lembaga terkait. Sementara itu, temuan penelitian menunjukkan bahwa $24 \%$ unit usaha telah menembus pasar nasional. Ketersediaan bahan baku juga terkendala karena $28 \%$ telah menembus pasar regional, sisanya $48 \%$ hanya mampu memasarkan produknya di wilayah lokal. Kelompok industri yang hanya menjangkau skala lokal, yaitu industri pelumatan, pengasapan, dan pemindangan, serta beberapa usaha makanan olahan hasil perikanan. Bagi industri yang mengalami jangkauan pasar yang rendah akibat minimnya ketersediaan bahan baku, maka dapat menggunakan bahan baku pengganti namun tetap mempertahankan kualitas produk sesuai dengan selera pasar.
\end{abstract}

Kata Kunci: bahan baku; pemasaran; promosi; produk; perikanan; industri pengolahan

\begin{abstract}
This study aimed to examine the availability of raw materials and the marketing scale of fish processing industry in South Konawe Regency. This research was conducted in 2017 and 2018 using primary and secondary data. Primary data were collected through questionnaires from 21 respondents. Secondary data were collected from Statistics Indonesia, Fisheries and Marine Affairs Office, and Industry and Trade Affairs of South Konawe Regency. Data were analyzed with descriptive analysis and SWOT analysis. The results found that raw material from local sources is the major force of fish processing industry. However, the fluctuating condition of its availability becomes the weakness. Fermentation, smoked fish, and dried fish processing industries suffer from this raw material problems. In addition, the availability of raw materials also largely depends on fishing results from small-scale traditional fishers. Therefore, the development of the fish industries need some specific improvement in the upstream section through the synergy on policies regarding raw material management from related institutions. Meanwhile, the research finding showed that $24 \%$ of business units have penetrated national market,
\end{abstract}


$28 \%$ have penetrated regional market, while the remaining $48 \%$ have only penetrated local market. The local industries were pulverized, smoked fish, fish brine, and some other fish processing industries. Those who could only reach small market area due to limited availability of raw materials are able to use substitute materials in a similar quality of market preferences.

Keywords: raw material; marketing; promotion; product; fishery; processing industry

\section{PENDAHULUAN}

Kabupaten Konawe Selatan memiliki potensi sumber daya alam yang melimpah sebagai keunggulan absolut, yang dapat dikembangkan menjadi keunggulan komparatif bahkan kompetitif dalam rangka peningkatan kesejahteraan rakyat. Salah satu potensi tersebut adalah sumber daya perairan laut. Adapun luas wilayah daratan Kabupaten Konawe Selatan, 451.420 ha atau $11,83 \%$ dari luas wilayah daratan Sulawesi Tenggara, dengan luas wilayah perairan laut 9.368 $\mathrm{km}^{2}$.

Pada dokumen Rencana Pembangunan Jangka Menengah Daerah (RPJMD) Kabupaten Konawe Selatan 2016-2021 bagian 2.1.3.4 tentang Kawasan Peruntukan Perikanan telah ditetapkan kawasan pengolahan hasil perikanan atau kawasan pengembangan minapolitan yang diarahkan pada daerah pesisir di sepanjang garis pantai Kabupaten Konawe Selatan dengan pusat pertumbuhan terdapat di Kecamatan Tinanggea dan Kolono (Bappeda Konawe Selatan, 2016). Sementara itu, industri pengolahan hasil perikanan meliputi tiga wilayah: (1) industri pengolahan rumput laut, yaitu pengeringan rumput laut yang terdapat di Kecamatan Tinanggea, Palangga Selatan, Lainea, Kolono, Moramo, dan Laonti serta pembuatan makanan ringan dan selai rumput laut terdapat di Kecamatan Kolono; (2) industri pengolahan perikanan, meliputi abon ikan, kerupuk ikan, dan ikan asin terdapat di seluruh kecamatan pesisir, serta pembuatan terasi dengan sentra pengembangan di Kecamatan Tinanggea, Lainea, dan Kolono; serta (3) rencana industri pembekuan di Kecamatan Tinanggea.

Pemerintah Daerah Kabupaten Konawe Selatan mengadaptasi konsep pembangunan minapolitan ke dalam visi pembangunan pada periode 2016-2021. Diharapkan konsep ini akan mendorong pendapatan masyarakat dan menyerap tenaga kerja. Hasil penelitian Tajerin, Kurniawan, \& Wicaksana (2015) menunjukkan bahwa pengembangan industri pengolahan produk perikanan Indonesia melalui peningkatan investasi sebesar $100 \%$ memberikan dampak terhadap perekonomian nasional berupa meningkatkan output ekonomi sebesar 0,83\% (107,97 triliun rupiah), nilai tambah bruto sebesar 0,48\% $(61,64$ triliun rupiah), pendapatan masyarakat sebesar $0,09 \%$ (11,33 triliun rupiah), dan penyerapan tenaga kerja sebesar $0,004 \%$ (503 ribu orang). Sasaran minapolitan di Kabupaten Konawe Selatan meliputi 105 desa yang ada wilayah pesisir yang tersebar dalam 9 kecamatan dari 23 kecamatan. Hilirisasi hasil-hasil perikanan dan kelautan untuk mendukung pencapaian minapolitan. Data Dinas Perindustrian dan Perdagangan Konawe Selatan (2017) menunjukkan bahwa pada tahun 2015, persentase jumlah industri perikanan sebesar 1,3\% dari total industri yang ada di wilayah tersebut, dan $63,33 \%$ masih berskala industri rumah tangga.

Rendahnya jumlah industri hasil perikanan disebabkan oleh beberapa kendala. Kendala tersebut berupa pemasaran, keuangan, manajemen usaha, dan keahlian pekerja (Omar, 2014). Hasil penelitian Madugu \& Edward (2011) dan Odebiyi, George, Odulate, Agbonlahor, \& Olaoye (2013) menunjukkan bahwa salah satu masalah yang dihadapi dalam pemasaran ikan olahan adalah buruknya transportasi yang menghubungkan pedesaan dan pusat kota. Hasil penelitian Ratnaningtyas, Ma'ruf, Agustini, Hutabarat, \& Anggoro (2016) pada industri pengolahan hasil perikanan, khususnya produk bandeng presto di Semarang, ditemukan bahwa meskipun pada aspek ekonomi berada pada indeks keberlangsungan cukup berlanjut, serta dari dimensi kualitas dan keamanan produk juga cukup berlanjut, namun dari dimensi ekologi dan bahan baku berada pada kategori kurang berlanjut. Permasalahan bahan baku juga menjadi kendala pengembangan usaha di Kabupaten Konawe Selatan. Hasil penelitian Rafiy, Ernawati, \& Surianti (2017) ditemukan bahwa produksi sektor hulu perikanan di Konawe Selatan tidak stabil atau fluktuatif. Data Dinas Kelautan dan Perikanan Konawe Selatan (2017) menunjukkan bahwa beberapa jenis industri seperti industri pelumatan dan industri pengolahan hasil kelautan lainnya memiliki keterbatasan pemasaran. Menurut Hakim (2012), promosi dan pemasaran merupakan salah satu strategi yang perlu diambil 
dalam upaya pengembangan produk perikanan dan kelautan, seperti yang terjadi di Kabupaten Biak Numfor (Wijayanto, 2016).

Penelitian ini bertujuan untuk mengidentifikasi ketersediaan bahan baku dan skala pemasaran pada industri hasil perikanan di Kabupaten Konawe Selatan, serta mengkaji strategi penanganan kendala bahan baku dan pemasaran. Strategi tersebut disusun berdasarkan pertimbangan kekuatan, kelemahan, dan peluang, serta tantangan yang dihadapi industri. Penelitian ini dilaksanakan pada tahun 2017 dan 2018. Penelitian menggunakan data primer dan data sekunder. Data primer diperoleh melalui kuesioner kepada 21 responden, sedangkan data sekunder diperoleh melalui Badan Pusat Statistik (BPS), Dinas Kelautan dan Perikanan (DKP), serta Dinas Perindustrian dan Perdagangan (Disperindag) Kabupaten Konawe Selatan. Data dianalisis secara deskriptif dengan bantuan tabulasi dan diagram. Penelitian ini juga menggunakan analisis SWOT (strengths, weaknesses, opportunities, and threats) atas aspek pemasaran dan ketersediaan bahan baku.

\section{KETERSEDIAAN BAHAN BAKU INDUSTRI PENGOLAHAN HASIL PERIKANAN}

Kabupaten Konawe Selatan memiliki enam jenis industri pengolahan hasil perikanan, yaitu industri fermentasi, pelumatan, pengasapan, pemindangan, pengeringan, dan industri lainnya (Tabel 1). Kelompok industri fermentasi menghasilkan produk terasi. Kelompok industri pelumatan menghasilkan bakso ikan tenggiri, cakalang, dan tuna. Adapun industri pengasapan menghasilkan ikan asap berbagai jenis, yaitu ikan tembang/lemuru, dan hanya satu jenis ikan yang diproduksi melalui proses pemindangan, yaitu ikan layang. Industri pengolahan hasil laut melalui proses pengeringan, membutuhkan bahan baku, seperti ikan bete-bete, dan jenis ikan lainnya.
Pengolahan hasil laut lainnya di Kabupaten Konawe Selatan telah menghasilkan beberapa jenis produk, yaitu dodol rumput laut, teri siap saji, kripik/krupuk ikan, abon ikan, dan bandeng presto. Industri pengolahan hasil perikanan di Kabupaten Konawe Selatan didominasi oleh industri pelumatan sebanyak 23 unit usaha, selanjutnya industri lainnya/aneka makanan hasil olahan sebanyak 17 unit usaha. Adapun industri yang masih terbatas jumlahnya adalah industri pemindangan dan pengasapan. Total industri pengolahan hasil perikanan di Kabupaten Konawe Selatan sebanyak 60 unit usaha dengan persebaran ditunjukkan pada Tabel 2 .

Persebaran industri pengolahan hasil perikanan di Kabupaten Konawe Selatan berdasarkan kecamatan menunjukkan bahwa Kecamatan Lainea memiliki keragaan produk pengolahan hasil perikanan dan kelautan terbanyak, sebanyak 9 produk, selanjutnya Kecamatan Laeya dengan 5 jenis produk, dan Kecamatan Tinanggea dengan 4 jenis produk. Terdapat kecamatan minapolitan yang belum memiliki industri pengolahan hasil perikanan, yaitu Kecamatan Laonti, Moramo Utara, Moramo, dan Kolono Timur. Beberapa kecamatan lain yang bukan terletak di kawasan minapolitan memiliki unit usaha yang bergerak dalam bidang pengolahan hasil laut. Jumlah unit usaha pada wilayah ini sebanyak 14 unit usaha, yang tersebar di Kecamatan Palangga sebanyak 5 unit usaha, Ranomeeto 1 unit usaha, Ranomeeto Barat 3 unit usaha, Baito 2 unit usaha, dan Konda 3 unit usaha.

Tabel 3 menyajikan ketersediaan bahan baku di industri pengolahan hasil kelautan dan perikanan di Kabupaten Konawe Selatan. Kendala ketersediaan bahan baku dialami oleh industri fermentasi, pengasapan, dan pengeringan ikan. Industri fermentasi mengakui bahwa kendala utama produksi terasi udang adalah bahan

Tabel 1. Jenis Industri Pengolahan Perikanan di Kabupaten Konawe Selatan Tahun 2016.

\begin{tabular}{cllc}
\hline No. & Jenis Industri & Produk & Jumlah Industri \\
\hline 1 & Fermentasi & Terasi Udang & 10 \\
2 & Pelumatan & Bakso lkan & 23 \\
3 & Pengasapan & Ikan Asap & 3 \\
4 & Pengeringan & Ikan Kering & 6 \\
5 & Pemindangan & Ikan Pindang & 1 \\
6 & Lainnya & Aneka Makanan Hasil Olahan & 17 \\
\hline
\end{tabular}

Sumber: Dinas Kelautan dan Perikanan Konawe Selatan, 2017; Dinas Perindustrian dan Perdagangan Konawe Selatan, 2017. 
Tabel 2. Sebaran Unit Usaha Industri Pengolahan Perikanan di Kawasan Minapolitan Kabupaten Konawe Selatan Tahun 2016.

\begin{tabular}{|c|c|c|c|c|c|c|c|c|}
\hline \multirow{2}{*}{ No } & \multirow{2}{*}{ Kecamatan } & \multicolumn{6}{|c|}{ Jumlah Jenis Usaha } & \multirow{2}{*}{ Total } \\
\hline & & Fermentasi & Pelumatan & Pengasapan & Pengeringan & Pemindangan & Lainnya & \\
\hline 1 & Tinanggea & 5 & - & - & - & - & 3 & 8 \\
\hline 2 & Laeya & 2 & 6 & 3 & 4 & - & 1 & 16 \\
\hline 3 & Lainea & 3 & 3 & - & 2 & 1 & 8 & 17 \\
\hline 4 & Kolono & - & 1 & - & - & - & 1 & 2 \\
\hline 5 & Kolono Timur & - & - & - & - & - & - & - \\
\hline 6 & Laonti & - & - & - & - & - & - & - \\
\hline 7 & $\begin{array}{l}\text { Palangga } \\
\text { Selatan }\end{array}$ & - & - & - & - & - & 3 & 3 \\
\hline 8 & Moramo & - & - & - & - & - & - & - \\
\hline 9 & Moramo Utara & - & - & - & - & - & - & - \\
\hline 10 & $\begin{array}{l}\text { Kecamatan } \\
\text { Lainnya }\end{array}$ & & 13 & - & - & - & 1 & 14 \\
\hline & Total & 10 & 23 & 3 & 6 & 1 & 17 & 60 \\
\hline
\end{tabular}

Sumber: Dinas Kelautan dan Perikanan Konawe Selatan, 2017; Dinas Perindustrian dan Perdagangan Konawe Selatan, 2017.

Tabel 3. Produksi dan Bahan Baku Industri Pengolahan Perikanan Kabupaten Konawe Selatan Tahun 2016.

\begin{tabular}{cllcll}
\hline No. & Jenis Industri & Produk & $\begin{array}{c}\text { Rata-rata Produksi } \\
\text { (Kg/Unit/BIn) }\end{array}$ & Bahan Baku & Ketersediaan \\
\hline 1. & Fermentasi & Terasi Udang & 200 & Ebi & Langka \\
2. & Pelumatan & Bakso Ikan & 83 & $\begin{array}{l}\text { Ikan Tenggiri, } \\
\text { Cakalang, Tuna } \\
\text { Ikan Tembang, } \\
\text { Lemuru }\end{array}$ & Tersedia \\
3. & Pengasapan & Ikan Asap & 267 & Ikan Layang & Tersedia \\
4. & Pemindangan & Ikan Pindang & 280 & $\begin{array}{l}\text { Bete-bete, Beberapa } \\
\text { Jenis Ikan Lainnya }\end{array}$ & Langka \\
5. & Pengeringan & Ikan Kering & 377 & $\begin{array}{l}\text { Teri } \\
\text { Rumput Laut, Ikan }\end{array}$ & Tersedia \\
6. & Industri Lainnya & Teri Siap Saji & 26 & $\begin{array}{l}\text { Berbagai Jenis } \\
\text { Ikan Cakalang, Tuna }\end{array}$ & Tersedia \\
& & Kripik, Krupuk & 20 & Ikan Bandeng & Tersedia \\
\hline
\end{tabular}

Sumber: Dinas Kelautan dan Perikanan Konawe Selatan, 2017.

baku berupa ebi (udang kering) yang masih langka dijual di pasar lokal. Kelangkaan ini membuat produsen langsung mengambil bahan baku udang dari alam (menangkap sendiri), sehingga membutuhkan modal yang tidak sedikit karena harus menyediakan alat tangkap berupa perahu dan perlengkapannya. Padahal industri fermentasi merupakan salah satu industri andalan di Kabupaten Konawe Selatan, dengan jumlah produksi mencapai $200 \mathrm{~kg}$ per bulan, per unit usaha.

Industri dengan produksi tertinggi adalah pengeringan ikan dengan produksi sebesar $377 \mathrm{~kg}$ per bulan per unit usaha, disusul industri pemindangan dan pengasapan ikan, yang secara berturut-turut sebesar $280 \mathrm{~kg}$ dan $267 \mathrm{~kg}$ per bulan per unit usaha. Produksi rata-rata industri pengolahan hasil perikanan lainnya per unit usaha masih di bawah $50 \mathrm{~kg}$ per bulan per unit usaha. Bahan baku diproses dengan bantuan teknologi maupun alat tradisional. Teknologi yang digunakan oleh unit usaha industri masih sederhana. Gambar 1 menunjukkan bahwa sebanyak 8 unit usaha dari 21 unit usaha yang diteliti atau 38\% telah menggunakan teknologi sederhana, sedangkan lainnya masih tradisional. Teknologi sederhana diadopsi oleh seluruh industri yang menghasilkan abon dan kripik krupuk ikan.Teknologi sederhana juga diterapkan pada industri fermentasi. Sebanyak 4 dari 7 industri fermentasi menggunakan teknologi sederhana dalam proses produksinya, khususnya mesin penggilingan bahan baku. 


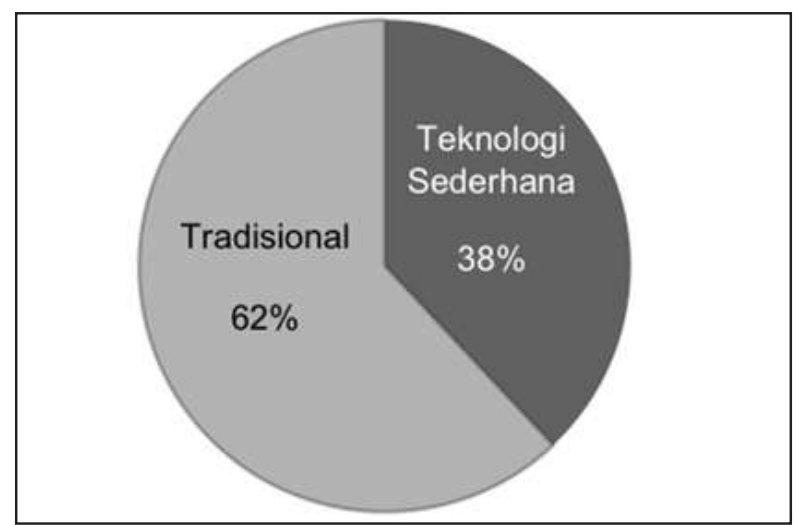

Gambar 1. Adopsi Teknologi pada Industri Perikanan Kabupaten Konawe Selatan Tahun 2017.

Sumber: Data Primer Diolah, 2017.

\section{SKALA PEMASARAN INDUSTRI PENGOLAHAN HASIL PERIKANAN}

Wilayah pemasaran industri hasil perikanan di Kabupaten Konawe Selatan disajikan pada Tabel 4, yang menunjukkan bahwa industri fermentasi telah mencapai skala nasional, salah satunya adalah Provinsi Nusa Tenggara Barat. Industri yang menembus pasar nasional ini khususnya berlokasi pada Kecamatan Laeya. Industri pelumatan, pengasapan, dan pemindangan ikan hanya mampu menjangkau skala lokal. Pada sisi lain, industri pengeringan telah mencapai skala provinsi. Hasil industri pengeringan ikan sebagian dipasarkan ke Kota Kendari dan Kabupaten Konawe. Industri makanan olahan hasil laut lainnya menunjukkan hanya produk teri siap saji yang telah menembus skala nasional, seperti Provinsi Papua. Kripik/ krupuk ikan dipasarkan pada skala provinsi. Adapun produk abon ikan dan bandeng presto hanya menjangkau skala lokal. Distribusi unit usaha berdasarkan jangkauan pemasaran yang

Tabel 4. Skala Pemasaran Industri Perikanan Konawe Selatan Tahun 2016

\begin{tabular}{|c|c|c|}
\hline No & Jenis Industri & Skala Pemasaran \\
\hline 1. & Fermentasi & Lokal, Provinsi, Nasional \\
\hline 2. & Pelumatan & Lokal \\
\hline 3. & Pengasapan & Lokal \\
\hline 4. & Pengeringan & Lokal, Provinsi \\
\hline 5. & Pemindangan & Lokal \\
\hline \multirow[t]{5}{*}{6.} & Industri Lainnya & \\
\hline & a. Abon Ikan & Lokal \\
\hline & b. Kripik, Krupuk & Lokal, Provinsi \\
\hline & c. Bandeng Presto & Lokal \\
\hline & d. Teri Siap Saji & Lokal, Nasional \\
\hline
\end{tabular}

Sumber: Dinas Kelautan dan Perikanan Konawe Selatan, 2017. disajikan pada Gambar 2 menunjukkan bahwa sebanyak $24 \%$ unit usaha telah menembus pasar nasional dan $28 \%$ telah menembus pasar regional provinsi. Sisanya sebanyak $48 \%$ hanya mampu memasarkan produknya di wilayah Kabupaten Konawe Selatan.

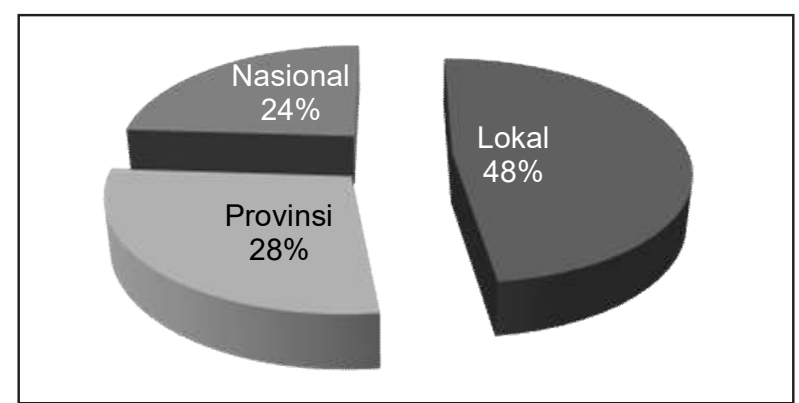

Gambar 2. Distribusi Industri Pengolahan Hasil Perikanan Kabupaten Konawe Selatan Berdasarkan Skala Pemasaran Tahun 2016.

Sumber: Dinas Kelautan dan Perikanan Konawe Selatan (2017)

Hasil penelitian menunjukkan bahwa terdapat enam industri pengolahan hasil kelautan dan perikanan yang berproduksi berdasarkan pesanan. Industri yang mengandalkan usaha pada pesanan adalah industri pelumatan (bakso ikan) dan industri makanan olahan lainnya (abon ikan dan teri siap saji). Pada sisi lain, sebanyak $14 \%$ atau $66,67 \%$ responden masih mengandalkan saluran pengenalan produk tatap muka. Terdapat 7 responden telah melakukan promosi usaha, khususnya dalam bentuk keikutsertaan dalam pameran yang dilakukan oleh pemerintah daerah. Penentuan harga produk pada industri pengolahan hasil perikanan seluruhnya ditentukan oleh produsen, yang menunjukkan bahwa produsen masih memiliki bargaining yang kuat atas konsumen. Hal ini juga mengindikasikan bahwa produk yang dijual oleh industri masih terbatas di pasar dapat dilihat pada Tabel 5 .

Industri perikanan di Kabupaten Konawe Selatan belum menggunakan teknologi informasi bagi pemasaran produknya. Sebagaimana ditunjukkan pada Gambar 3 bahwa saluran distribusi industri, selain ke konsumen langsung, juga menggunakan agen. Terdapat 2 unit usaha yang hanya memiliki saluran distribusi agen, yang disebabkan baik karena jarak lokasi produksi ke konsumen akhir maupun karena belum adanya toko/kios/stand pemasaran yang dimiliki. Pada sisi lain, terdapat 10 unit usaha yang menggunakan saluran distribusi baik agen maupun konsumen langsung. 
Tabel 5. Distribusi Responden Berdasarkan Tipe Produk dan Saluran Promosi Industri Perikanan Konawe Selatan Tahun 2017.

\begin{tabular}{rlcccc}
\hline \multirow{2}{*}{ No } & \multicolumn{2}{c}{ Jenis Industri } & \multicolumn{2}{c}{ Tipe Produk } & \multicolumn{2}{c}{ Saluran Promosi } \\
\cline { 3 - 5 } & & Massa & Pesanan & Tatap Muka & Pameran \\
\hline 1. & Fermentasi & 7 & - & 7 & 3 \\
2. & Pelumatan & - & 2 & 2 & - \\
3. & Pengasapan & 2 & - & 2 & - \\
4. & Pengeringan & 4 & - & 4 & 1 \\
5. & Industri Lainnya & & & 3 & - \\
& a. Abon Ikan & - & 3 & 1 & 1 \\
& b. Kripik,Krupuk & 1 & - & 1 & - \\
\hline
\end{tabular}

Sumber: Data Primer Diolah, 2017.

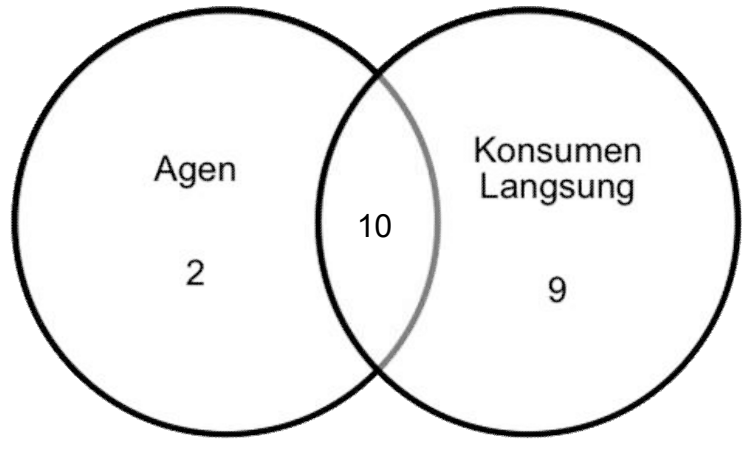

Gambar 3. Jumlah Responden Berdasarkan Saluran Distribusi Industri Perikanan Konawe Selatan Tahun 2017.

Sumber: Data Primer (2017), Diolah

\section{STRATEGI PENGEMBANGAN INDUSTRI PENGOLAHAN HASIL PERIKANAN}

Rencana Strategis Disperindag Kabupaten Konawe Selatan Periode 2016-2021 (Dinas Perindustrian dan Perdagangan Konawe Selatan, 2016) menyajikan kondisi internal (kekuatan dan kelemahan) dan kondisi eksternal (peluang dan ancaman) yang dihadapi dalam pengembangan industri di Kabupaten Konawe Selatan. Kekuatan industri adalah (1) besarnya potensi industri skala rumah tangga dan kecil; (2) adanya sentra usaha Industri Kecil dan Menengah (IKM) berdasarkan komoditi; (3) terbentuknya struktur organisasi dinas sebagai pembina industri; (4) adanya event-event promosi dan temu usaha bagi IKM; (5) tersedianya database industri Kabupaten Konawe Selatan; serta (6) Pemerintah Kabupaten Konawe Selatan konsisten mengembangkan Usaha Mikro Kecil dan Menengah (UMKM). Adapun kelemahan industri di wilayah tersebut adalah (1) masih terbatasnya Anggaran Pendapatan dan Belanja Daerah (APBD) untuk pembinaan industri;
(2) rendahnya jiwa kewirausahaan pelaku usaha, penguasaan teknologi produksi, orientasi pada mutu dan daya inovasi serta kegiatan usaha industri berbasis sumber daya lokal; (3) masih belum adanya kawasan industri yang benar-benar mumpuni; (4) masih terbatasnya kemampuan mengakses pasar dan institusi pemasaran di Kabupaten Konawe Selatan; (5) belum terwujudnya komitmen, konsistensi kebijakan, dan keterpaduan berbagai pihak dalam pengembangan IKM; (6) tidak adanya tenaga ahli di bidang industri karena terbatasnya kesempatan untuk mendapatkan pendidikan teknis fungsional; serta (7) struktur industri belum tertata secara baik.

Peluang yang dihadapi pemerintah daerah dalam pengembangan industri adalah (1) adanya visi, misi, dan program unggulan Kabupaten Konawe Selatan yang mendukung pengembangan UMKM; (2) terbukanya peluang kerja sama dengan perguruan tinggi, lembaga desain, konsultan, lembaga riset, dan lembaga pengujian; (3) adanya kebijakan pemerintah pusat dan provinsi yang konsisten mendukung perkembangan industri di daerah; (4) pemberlakukan Standar Nasional Indonesia (SNI) secara wajib dan sukarela; (5) Kabupaten Konawe Selatan berada pada posisi strategis; (6) tersedianya potensi produk pertanian, peternakan, perkebunan, dan kehutanan di sekitar Kabupaten Konawe Selatan yang dapat mendukung perkembangan industri di Kabupaten Konawe Selatan; serta (7) kesepakatan Masyarakat Ekonomi ASEAN (MEA) 2015 dan Pasar Global 2020. Tantangan yang dihadapi dalam pengembangan industri adalah (1) sebagian industri masih memiliki ketergantungan yang besar terhadap bahan baku, bahan penolong, barang setengah jadi, dan komponen dari luar daerah; (2) tingginya 
biaya faktor produksi produk IKM mengakibatkan kurangnya daya saing; serta (3) masih adanya kecenderungan masyarakat menyukai produk luar negeri.

Pada sisi lain, hasil penelitian menunjukkan masih terdapat kekuatan, kelemahan, peluang, dan ancaman pengembangan industri khususnya pengolahan hasil perikanan terkait dengan ketersediaan bahan baku dan skala pemasaran, sebagaimana disajikan pada Tabel 6. Namun, bahan baku industri bersumber dari potensi lokal yang ketersediaannya masih fluktuatif.

Salah satu penyebab fluktuasi bahan baku industri pengolahan adalah terbatasnya kuantitas serta kualitas sarana dan prasarana penangkapan ikan. Kapal yang beroperasi di perairan Kabupaten Konawe Selatan rata-rata hanya di bawah 10 GT, sedangkan dengan jenis perairan di seputaran Laut Banda dan sekitarnya dibutuhkan kapal di atas 20 - 30 GT. Nelayan tradisional dengan struktur armada yang relatif kecil maka akan berpengaruh terhadap daya jangkau tangkapan yang pada akhirnya berpengaruh terhadap kuantitas tangkapan. Hal ini akan mengancam ketersediaan bahan baku industri pengolahan hasil perikanan yang sustainable dalam jangka panjang. Namun hal yang dapat dijadikan peluang dalam penanganan ketersediaan bahan baku adalah beberapa bahan baku industri hasil perikanan dapat dibudidayakan.

Produk industri memiliki pesaing dari daerah lain, namun pelaku industri masih memiliki peluang pemasaran dengan tingginya potensi sumber daya manusia sebagai potensi demand produk. Sumber daya manusia menjadi kekuatan penting dalam mengembangkan industri hasil perikanan di Kabupaten Konawe Selatan. Berdasarkan data Badan Pusat Statistik Kabupaten Konawe Selatan (2018), jumlah penduduk Konawe Selatan pada tahun 2016 sebesar 299.928 jiwa, yang terdiri dari 152.710 jiwa laki-laki, dan 147.218 jiwa perempuan, dengan laju pertumbuhan penduduk (2015-2016) 1,56\%, sedangkan rata-rata pertumbuhan sejak tahun 2010 sebesar 3\% per tahun. Peluang pengembangan industri aspek pemasaran juga bersumber dari perkembangan media online sebagai peluang pemasaran dan promosi.

Berdasarkan kekuatan, kelemahan, peluang, dan tantangan yang dipaparkan tersebut, maka beberapa strategi yang dapat ditempuh dalam upaya penanganan keterbatasan bahan baku adalah (1) Manajemen ketersediaan bahan baku; (2) Pencetakan lahan pembudidayaan hasil laut/ perikanan; serta (3) Bantuan modal bagi UKM kelautan dan perikanan. Ketiga strategi tersebut merupakan strategi sektor hulu perikanan. Dengan demikian, diperlukan sinergitas dan keterpaduan kebijakan hulu-hilir lembaga pemerintah yang terkait dengan perikanan dan kelautan.

Strategi pemasaran dan promosi yang dapat ditempuh dalam upaya peningkatan skala pemasaran adalah (1) pelatihan promosi dan pemasaran online; (2) pembentukan jaringan promosi/pemasaran dengan industri terkait (rumah makan, hotel/restoran, pariwisata, pasar modern, dan lain-lain); (3) insentif partisipasi promosi pada skala provinsi dan nasional; serta (4) penyediaan sarana penunjang perdagangan berupa rumah promosi bagi IKM.

Industri pengolahan hasil perikanan di Kabupaten Konawe Selatan dihadapkan pada keterbatasan bahan baku. Temuan ini sejalan dengan temuan Ceyhan \& Emir (2015) dan Hikmayani, Aprilliani, \& Adi (2017). Industri fermentasi membutuhkan ebi (udang kering) sebagai bahan baku utama. Keterbatasan bahan baku pada industri fermentasi mendorong

Tabel 6. Kondisi Internal dan Eksternal Bahan Baku serta Pemasaran pada Industri Pengolahan Hasil Perikanan di Kabupaten Konawe Selatan Tahun 2018.

\begin{tabular}{|c|c|c|c|}
\hline No & Uraian & Aspek Bahan Baku & Aspek Pemasaran \\
\hline 1. & Kekuatan & Bahan baku dari potensi lokal & n.a \\
\hline 2. & Kelemahan & Ketersediaan yang fluktuatif & n.a \\
\hline 3. & Peluang & $\begin{array}{l}\text { Beberapa sumber bahan baku dapat } \\
\text { dibudidayakan }\end{array}$ & $\begin{array}{l}\text { Besarnya potensi sumber daya manusia } \\
\text { Berkembangnya media online dan } \\
\text { transaksi jual beli E-commerce }\end{array}$ \\
\hline 4. & Ancaman & $\begin{array}{l}\text { Kuantitas dan kualitas sarana } \\
\text { prasarana penangkapan ikan terbatas }\end{array}$ & Banyaknya produk sejenis dari daerah lain \\
\hline
\end{tabular}

Sumber: Data Primer Diolah, 2018. 
beberapa unit usaha melakukan penangkapan secara langsung. Industri pengasapan dan pengeringan ikan menggunakan ikan berbagai jenis dalam proses produksi. Bahan baku industri tersebut bersifat fluktuatif yang disebabkan oleh faktor musim termasuk perubahan iklim (Lubis, Nugroho, \& Witry, 2013) serta disebabkan minimnya kuantitas dan kualitas sarana penangkapan ikan. Data Badan Pusat Statistik Kabupaten Konawe Selatan (2018) menunjukkan bahwa jumlah perahu/kapal di Kabupaten Konawe Selatan pada tahun 2017 sebanyak 4.432 unit yang didominasi oleh perahu tanpa motor sebanyak 2.969 unit, dan tidak mengalami peningkatan dari tahun sebelumnya. Sebagian besar sumber bahan baku industri berasal dari nelayan tradisional dan struktur armada perikanan didominasi skala kecil. Dengan demikian, perbaikan sektor hulu sangat penting untuk dilakukan khususnya penyediaan sarana dan prasarana penangkapan ikan. Studi Failler, Pan, Thorpe, \& Tokrisna (2014) menemukan bahwa efek pengganda dari perikanan tangkap pada sektor pengolahan dan perdagangan ikan adalah empat kali lipat. Oleh karena itu diperlukan sinergitas antar lembaga hulu-hilir sektor kelautan dan perikanan. Penyediaan sarana dan prasarana penangkapan ikan dapat bersumber dari lembaga komersial, maupun pemerintah. Sumber pendanaan komersial, misalnya perbankan dan lembaga keuangan lainnya. Berdasarkan data Badan Pusat Statistik Kabupaten Konawe Selatan (2018), jumlah kantor bank di Konawe Selatan sebanyak 14 unit dan jumlah koperasi sebanyak 301 unit dengan jumlah modal 365,57 miliar rupiah.

Pendanaan pemerintah dapat bersumber dari Anggaran Pendapatan dan Belanja Daerah (APBD). Namun karena keterbatasan APBD, maka diperlukan dukungan dari Anggaran Pendapatan dan Belanja Negara (APBN). Salah satu jalur yang dapat digunakan dalam pengembangan usaha perikanan adalah alokasi dana desa (ADD). Dasar Peraturan Desa dan Dana Desa antara lain: (1) Undang-Undang Nomor 6 Tahun 2014 tentang Desa, (2) Peraturan Pemerintah Nomor 47 Tahun 2015 tentang Perubahan atas Peraturan Pemerintah Nomor 43/2014 tentang Peraturan Pelaksanaan Undang-Undang Nomor 6 Tahun 2014, serta (3) Peraturan Pemerintah Nomor 8 Tahun 2016 Tentang Perubahan atas Peraturan Pemerintah Nomor 60/2014 tentang Dana Desa yang bersumber dari APBN. Peluang alokasi tersebut diizinkan oleh peraturan yang ada, karena fokus ADD bukan hanya pembangunan dan penyelenggaraan pemerintahan, namun juga pemberdayaan dan pembinaan masyarakat. Data Kementerian Keuangan Republik Indonesia (2017) menunjukkan bahwa pada tahun 2015 dana pemberdayaan masyarakat melalui ADD sebesar 1,37 triliun rupiah atau sekitar 7,7\% dari total alokasi pada tahun tersebut. Sedangkan pada tahun 2016 meningkat menjadi 3,17 triliun rupiah meskipun proporsinya hanya 6,8\% dari alokasi ADD. Adapun ADD Kabupaten Konawe Selatan tahun anggaran 2017 sebesar 252,3 miliar rupiah. Peluang penggunaan ADD sebagai sumber pengembangan industri berbasis kelautan dan perikanan, bahwa wilayah yang termasuk daerah industri hasil kelautan dan perikanan masih berstatus desa, dan masih berupa industri rumah tangga, serta sesuai dengan Peraturan Menteri Desa Nomor 19 Tahun 2017, prioritas ADD adalah pembangunan desa dan pemberdayaan masyarakat desa.

Pada sisi lain, keterbatasan bahan baku yang dialami oleh beberapa industri tentunya akan berdampak pada rendahnya jangkauan pemasaran. Menurut Hikmayani, Apriliani, \& Adi (2017), kelangkaan bahan baku dapat disiasati salah satunya dengan penggunaan bahan baku lain sebagai subtitusi. Pihak industri dapat menyiasati kendala ini dengan menggunakan bahan baku pengganti yang melimpah dengan memperhatikan selera pasar. Skala pemasaran industri pelumatan, pengasapan, dan pemindangan hanya menjangkau skala lokal. Industri pengasapan dan pemindangan secara rata-rata per unit usaha telah mencapai produksi secara berturut-turut $267 \mathrm{~kg}$ dan $280 \mathrm{~kg}$ per bulan. Hal tersebut mengindikasikan tingginya animo masyarakat akan kedua produk tersebut. Pengembangan industri perikanan di Kabupaten Konawe Selatan perlu pula ditekankan pada industri pelumatan yang memiliki pangsa pasar minim, dengan produksi < $100 \mathrm{~kg}$ per bulan per unit usaha. Industri olahan makanan lainnya, seperti: kripik/krupuk, dodol rumput laut, abon ikan, maupun ikan presto dengan produksi < $50 \mathrm{~kg}$ per bulan per unit usaha.

Shofa \& Navastara (2015) menemukan bahwa aspek pemasaran dalam pengembangan industri pengolahan perikanan dipengaruhi pula oleh variabel ketersediaan pasar, permintaan pasar, dan strategi pemasaran. Strategi pemasaran salah satunya dilakukan dengan kegiatan promosi, baik dengan memanfaatkan media online maupun offline. Selain hal tersebut, diperlukan 
pula pembentukan jaringan promosi/pemasaran dengan industri terkait, seperti rumah makan untuk industri makanan olahan ikan dan pasar modern bagi industi pelumatan maupun makanan olahan. Pemerintah juga perlu menyediakan sarana penunjang perdagangan berupa rumah promosi bagi IKM. Rumah promosi tersebut dapat memanfaatkan sentra IKM sebagai pusat promosi industri berbasis teknologi informasi. Selanjutnya, guna memotivasi industri untuk terlibat dalam kegiatan promosi, pemerintah dapat memberikan insentif partisipasi promosi pada skala provinsi dan nasional maupun kabupaten. IKM perlu dimotivasi pada kegiatan promosi IKM di Kabupaten Konawe Selatan yang telah terjadwal setiap tahunnya, yaitu expo atau pameran pembangunan Kabupaten Konawe Selatan yang digelar dalam rangka HUT Kabupaten Konawe Selatan setiap tanggal 2 Mei, dan Pameran Pembangunan Provinsi Sulawesi Tenggara sebagai agenda tahunan yang dilaksanakan dalam rangka hari jadi Sulawesi Tenggara.

\section{PENUTUP}

Kendala bahan baku pada industri perikanan di Kabupaten Konawe Selatan disebabkan ketersediaan bahan baku tersebut bersifat fluktuatif. Fluktuasi bahan baku selain karena faktor musiman juga karena sebagian besar sumber bahan baku industri berasal dari nelayan tradisional dan struktur armada perikanan didominasi skala kecil. Industri hasil perikanan juga dihadapkan pada persoalan pemasaran. Industri fermentasi telah menembus pasar provinsi maupun nasional, dan industri pengeringan telah menembus pasar provinsi. Sementara itu, industri pelumatan dan beberapa jenis produk makanan olahan hasil perikanan, seperti abon ikan dan bandeng presto hanya mampu menjangkau pasar lokal.

Upaya-upaya yang perlu dilakukan pemerintah daerah dalam menangani keterbatasan bahan baku, yaitu manajemen ketersediaan bahan baku, pencetakan lahan pembudidayaan hasil laut/perikanan, dan insentif modal bagi pelaku usaha UMKM kelautan dan perikanan. Beberapa upaya yang dapat dilakukan pemerintah daerah dalam menangani keterbatasan pemasaran di antaranya kegiatan pelatihan promosi dan pemasaran online, pembentukan jaringan promosi/ pemasaran, insentif partisipasi promosi usaha, serta penyediaan sarana penunjang perdagangan, seperti rumah promosi.
Keterbatasan bahan baku merupakan permasalahan di sektor hulu perikanan. Oleh karena itu, pengembangan industri hasil perikanan membutuhkan perbaikan di sektor hulu melalui sinergitas kebijakan penanganan keterbatasan bahan baku dari lembaga terkait. Upaya-upaya penetrasi pasar baik melalui peningkatan kapasitas pelaku usaha dalam mendesain media promosi dan jaringan kerja sama, dan penyediaan sarana dan prasarana promosi sebagai solusi dari masalah pemasaran.

\section{UCAPAN TERIMA KASIH}

Penelitian ini dapat terlaksana dengan adanya bantuan dana Hibah Penelitian Terapan Unggulan Perguruan Tinggi (PTUPT) Direktorat Jenderal Pendidikan Tinggi Tahun 2017-2018. Kami mengucapkan terima kasih atas kerja samanya kepada Dinas Perikanan dan Kelautan, Dinas Perindustrian dan Perdagangan, serta Badan Perencanaan Pembangunan Daerah Kabupaten Konawe Selatan.

\section{PERNYATAAN KONTRIBUSI PENULIS}

Dengan ini kami menyatakan bahwa kontribusi masing-masing penulis terhadap pembuatan karya tulis adalah Ernawati sebagai kontributor utama. Muhammad Rafiy dan Surianti sebagai kontributor anggota. Penulis menyatakan bahwa telah melampirkan surat pernyataan kontribusi penulis.

\section{DAFTAR PUSTAKA}

Badan Pusat Statistik Kabupaten Konawe Selatan. (2018). Kabupaten Konawe Selatan Dalam Angka 2018. BPS Kabupaten Konawe Selatan. Nomor Publikasi: 74050.1803. Katalog: 1102001.7405

Bappeda Konawe Selatan. (2016). RPJMD Kabupaten Konawe Selatan Tahun 2016-2021. Bappeda Konawe Selatan

Ceyhan, V., \& Emir, M. (2015). Structural and economic analysis of Turkish fishmeal and fish oil industry. Turkish Journal of Fisheries and Aquatic Sciences, Vol 15(4), 841-850. doi: 10.4194/13032712-v15_4_07

Dinas Kelautan dan Perikanan Konawe Selatan. (2017). Data Perusahaan Pengelola Hasil Kelautan dan Perikanan Konawe Selatan. DKP Konawe Selatan

Dinas Perindustrian dan Perdagangan Konawe Selatan. (2016). Rencana Strategis 2016-2021 Dinas 
Perindustrian dan Perdagangan. Disperindag Konawe Selatan

Dinas Perindustrian dan Perdagangan Konawe Selatan. (2017). Data IKM Tahun 2016. Dinas Perindustrian dan Perdagangan Konawe Selatan

Failler, P., Pan, H., Thorpe, A., \& Tokrisna, R. (2014). On macroeconomic impact of fishing effort regulation: measuring bottom-up fish harvesters' economy-wide contribution. Natural Resources, Vol 5(07), 269-281. doi :10.4236/ nr.2014.57025

Hakim, M. F. (2012). Blue economy daerah pesisir berbasis kelautan dan perikanan. Economics Development Analysis Journal, Vol 2(2), 1-7. doi: 10.15294/edaj.v2i2.1756

Hikmayani, Y., Apriliani, T., \& Adi, T. R. (2017). Alternatif solusi bagi keberlanjutan industri surimi di Indonesia. Buletin IImiah Marina Sosial Ekonomi Kelautan dan Perikanan, Vol 3(1), 39-50. doi: 10.15578/marina.v3i1.6100

Kementerian Keuangan Republik Indonesia. (2017). Buku Pintar Dana Desa: Dana Desa untuk Kesejahteraan Masyarakat: Menciptakan Lapangan Kerja, Mengatasi Kesenjangan, dan Mengentaskan Kemiskinan. Jakarta, ID: Kemenkeu RI

Lubis, E., Nugroho, T., \& Witry, S. D. B. (2013). Produksi hasil tangkapan sebagai bahan baku industri pengolahan: Kasus Pelabuhan Perikanan Pantai Muncar Kabupaten Banyuwangi. Buletin PSP, Vol 21(1), 77-95. Retrieved from http:// journal.ipb.ac.id/index.php/bulpsp/article/ view/7120/11971

Madugu, A. J., \& Edward, A. (2011). Marketing and distribution channel of processed fish in Adamawa State. Nigeria Global Journal of Science Frontier Research Agriculture and Veterinary, Vol 11(4), 20-26. Retrieved from https://journalofbusiness.org/index.php/GJMBR/ article/view/481/428

Odebiyi, O. C , George, F. O. A , Odulate, D. O., Agbonlahor, M. U., \& Olaoye O. J. (2013). Value-chain analysis for coastal fisheries development in Nigeria. Global Journal of Science Frontier Research Agriculture and Veterinary, Vol 13(11), 1-14. Retrieved from https://globaljournals.org/GJSFR_Volume13/2-Value-ChainAnalysis-for-Coastal-Fisheries.pdf

Omar, A. (2014). The marketing of small and medium enterprise (SME) products based on food processing. European Journal of Business and Social Sciences, Vol 3(5), 76-87. Retrieved from http://www.ejbss.com/recent.aspx
Peraturan Menteri Desa Nomor 19 Tahun 2017 Tentang Penetapan Prioritas Penggunaan Dana Desa Tahun 2018. Ditetapkan tanggal 22 September 2017. Jakarta, ID: Kementerian Desa, Pembagunan Daerah Tertinggal dan Transmigrasi

Peraturan Pemerintah Nomor 47 Tahun 2015 Tentang Perubahan atas Peraturan Pemerintah 43/2014 Tentang Peraturan Pelaksanaan UU 6/2014. Ditetapkan tanggal 30 Juni 2015. Jakarta

Peraturan Pemerintah Nomor 8 Tahun 2016 Tentang Perubahan atas Peraturan Pemerintah 60/2014 Tentang Dana Desa yang Bersumber dari APBN. Ditetapkan tanggal 24 Maret 2016. Jakarta

Rafiy, M., Ernawati, \& Surianti (2017). Kinerja Keunggulan Bersaing Komoditas Minapolitan Kabupaten Konawe Selatan. Prosiding Seminakel XII Universitas Hang Tuah Surabaya, A13-19

Ratnaningtyas, N. A., Ma'ruf, W. F, Agustini, T. W., Hutabarat, J., \& Anggoro, B. (2016). Prospect and adversity the downstream of softbone milkfish in Semarang City, Indonesia. Aquatic Procedia, 7, 166 - 176. doi: 10.1016/j.aqpro.2016.07.023

Shofa, S. U. \& Navastara, A. M. (2015). Faktor penentu pengembangan industri pengolahan perikanan di Kabupaten Sidoarjo melalui pengembangan ekonomi lokal. Jurnal Teknik ITS, Vol 4(2), 76-80. doi: 10.12962/j23373539.v4i2.10863

Tajerin, Kurniawan, T., \& Wicaksana, R. M. N. (2015). Dampak peningkatan investasi untuk pengembangan industri pengolahan produk perikanan Indonesia terhadap perekonomian nasional. Buletin Ilmiah "MARINA" Sosial Ekonomi Kelautan dan Perikanan, Vol 1(2), 89-107. doi: 10.15578/marina.v1i2.2075

Undang-Undang Nomor 6 Tahun 2014 Tentang Desa. Ditetapkan tanggal 15 Januari 2014. Jakarta

Wijayanto, D. (2016). Fisheries development strategies of Biak Numfor Regency, Indonesia. Aquatic Procedia, 7, 28 - 38. doi : 10.1016/j. aqpro.2016.07.004 